\title{
Universiteit
}

Leiden

The Netherlands

\section{The Legal Regime for Free Trade in the Commonwealth of Independent} States

Kort, J.F. de; Dragneva, R.O.

\section{Citation}

Kort, J. F. de, \& Dragneva, R. O. (2007). The Legal Regime for Free Trade in the Commonwealth of Independent States. International And Comparative Law Quarterly, 56(April 2007), 233-266. Retrieved from https://hdl.handle.net/1887/43269

Version: $\quad$ Not Applicable (or Unknown)

License:

Downloaded from: https://hdl.handle.net/1887/43269

Note: To cite this publication please use the final published version (if applicable). 


\title{
LEGAL REGIME FOR FREE TRADE IN THE COMMONWEALTH OF \\ INDEPENDENT STATES
}

\author{
RILKA DRAGNEVA* \\ JOOP DE KORT**
}

\section{INTRODUCTION}

The dissolution of the Soviet Union and the transition of its former constituent republics to independent statehood entailed the end of the single economic system of the USSR. The successor states faced the challenge of setting up new, this time international economic relations among themselves, while engaging in state-building and trying to overcome the negative economic effects of the break-up. ${ }^{1}$ The Commonwealth of Independent States (CIS) was found in December 1991 as the institutional framework to manage and foster these relations. Nonetheless, the CIS has not been as effective in

\footnotetext{
* Lecturer, School of Law, University of Manchester, U.K., Faculty of Law, University of Leiden, Netherlands (rodragneva@yahoo.co.uk). The research on which this article is based was funded by the Dutch Organization for Scientific Research (NWO). The authors thank the members of the Leiden Institute of East European Law and Russian Studies for helpful comments on earlier drafts of this article, and the anonymous referee(s) for the suggestions for improvement.

**Lecturer, Department of Tax Law and Economics, Faculty of Law, Department of Russian Studies and Slavic Languages and Cultures, Faculty of Arts, University of Leiden (j.f.dekort@law.leidenuniv.nl).

${ }^{1}$ In view of the different course of integration of the Baltic states, namely membership in the European Union, we deal only with the remaining former Soviet republics: Armenia, Azerbaijan, Belarus, Georgia, Moldova, Kazakhstan, Kyrgyz Republic, The Russian Federation, Tajikistan, Ukraine, and Uzbekistan. Turkmenistan has changed its status from a full member to an observer in August 2005, yet we continue to consider it where appropriate.
} 
providing a viable framework for (re)integration as it has been in facilitating the managed disintegration of the USSR. Indeed, for many commentators both in the West and the East, the CIS formula has largely failed. ${ }^{2}$

The starting point of this work, however, is the belief in the limiting nature of 'failure-success' paradigms. Such approaches tend to distract the attention from the functional value of actual developments, obscure the understanding of the learning processes taking place, and can easily overestimate the applicability of selected normative models. While we are far from the idea to revive any myths of the 'bright future' of the CIS unity, we find it important to look into one area, namely trade in goods, where regional cooperation makes sense. ${ }^{3}$ Whether through the CIS framework or despite it, intra-CIS trade still represents a relatively high percentage of the trade portfolios of the individual newly independent states; trade reorientation, while undoubtedly occurring, has proved to be a slow and complex process. ${ }^{4}$ Indeed, the importance of regional cooperation between the former Soviet republics - domestically but also in view of their contribution to global trade - has been recently underscored in a series of studies

\footnotetext{
${ }^{2}$ M Brill Olcott et al Getting It Wrong: Regional Cooperation and the Commonwealth of Independent States (Carnegie Endowment Washington DC 1999); JV Shishkov Integratsionnye processy na poroge XXI veka (III Tysiacheletie Moskva 2001).

${ }^{3}$ We are aware that we simplify what is a burgeoning discussion on the benefits of regionalism, particularly in relation to the participation in the multilateral system of trade.

${ }^{4}$ For more on trade patterns between the CIS countries, see L Freinkman et al 'Trade Performance and Regional Integration of the CIS Countries' World Bank Working Paper No 38, The World Bank, Washington DC (2004); S Djankov and C Freund 'Trade Flows in the Former Soviet Union, 1987 to 1996' (2002) 30 Journal of Comparative Economics, 76-90; K Elborgh-Woytek 'Of Openness and Distance: Trade Developments in the Commonwealth of Independent States, 1993-2002' IMF Working Paper No 03/207 (2003).
} 
conducted under the auspices of international institutions, such as the World Bank, IMF and the UNECE. ${ }^{5}$

We find it particularly important to focus on the institutional framework for trade in the post-Soviet space and its role in fostering (or preventing) effective regional cooperation. In doing so we are driven by two main concerns. Firstly, many opinions point to implementation and compliance with existing legal instruments as the main problem in enabling effective economic integration in the CIS. We take a step back, however, and seek to underscore the value of putting in place good quality legal institutions to facilitate economic processes, ${ }^{6}$ and, importantly, to promote compliance. ${ }^{7}$

Secondly, increasing legalization (or juridicization) has characterized the evolution of various trade regimes - global multilateral, regional or bilateral - over the last fifty years. ${ }^{8}$ Indeed, for understandable reasons, there is often the tendency to associate success of integration with advanced juridicization. While we see the value of higher legalization in the CIS, we note that legalization in general comes about after a period of development (including confidence-building) and/or through the confluence of particular

\footnotetext{
${ }^{5}$ In addition to the studies mentioned in $\mathrm{n} 4$, see UNECE 'Building Partnerships in the CIS Region', TRADE/2005/17 (2005); P Tumbarello ‘Regional Trade Integration and WTO Accession’ IMF Working Paper No 05/94 (2005).

${ }^{6}$ D Rodrik et al 'Institutions Rule: The Primacy of Institutions over Geography and Integration in Economic Development’ NBER Working Paper No 9305 (NBER Cambridge Massachusetts 2002).

${ }^{7}$ A Chayes and AH Chayes The New Sovereignty: Compliance with International Regulatory Agreements (Cambridge Massachusetts Harvard University Press 1995). The authors argue that poor quality of treaty provisions in particular is a key source of non-compliance.

${ }^{8}$ A Reich 'From Diplomacy To Law: The Juridicization of International Trade Relations' (1996) 17: 2/3 Northwestern Journal of International Law and Business.
} 
favourable factors. ${ }^{9}$ Furthermore, as recent studies have shown, rather than necessarily being failed 'hard' regimes, 'softer' forms of legalization of international relations present certain advantages to the participating states. ${ }^{10}$

Thus, we examine and evaluate the institutional framework for trade in the postSoviet space in its development over time. For the purposes of this article, we use the term "institutions" to describe the set of rules, norms and decision-making procedures which shape the behaviour of member states in the area of trade as embodied in the international agreements concluded among them and the acts of the bodies (or organs) of the CIS. ${ }^{11}$ We begin by providing a general background to the development of the CIS trade regime. We note, in particular, the multiplication of regimes for trade in goods at the bilateral and the CIS multilateral level. ${ }^{12}$ We proceed to examine the legal features of the sources of the regimes. We continue by discussing the substantive scope and strength of commitments they embody, and point to the implications of their overlap. The analysis focuses on the most important multilateral agreements concluded within the CIS since

\footnotetext{
${ }^{9}$ F Duina The Social Construction of Free Trade (Princeton University Press Princeton and Oxford 2006). On the range of explanatory factors behind different forms of legalization see M Kahler 'The Causes and Consequences of Legalization’ (2000) 3 International Organization 661-683.

${ }^{10} \mathrm{~K}$ Abbott and D Snidal “'Hard” and "Soft” in International Governance', (2000) 3 International Organization 421-456. For a discussion of this argument in the CIS context see R Dragneva "Is "Soft" Beautiful? Another Perspective on Law, Institutions, and Integration in the CIS’ (2004) 29:3 Review of Central and East European Law 279-324.

${ }^{11}$ In doing so, we use the terms "institutions", "institutional framework", and "regime” as synonyms.

${ }^{12}$ We use the terms 'bilateral' and 'multilateral' with reference to numbers of signatories, rather other possible defining criteria, see J Van Oudenaren 'What is “Multilateral”?', (2003) Policy Review No 117. Where needed we sub-divide the 'multilateral' category into 'global multilateral' (eg WTO, UN, IMF arrangements), 'regional' (eg CIS, EU, NAFTA) or 'sub-regional' (with reference to formations within the regional ones).
} 
1991 as well as on a sample of bilateral agreements related to trade in goods. ${ }^{13}$ The sample of bilateral agreements covers more than half of such agreements and protocols concluded since 1992, with a greater bias towards the bigger CIS member states, such as Russia, Ukraine and Kazakhstan. ${ }^{14}$ Finally, we discuss the implications of our findings in terms of the functional value of the different regime institutions and in terms of the likely scenarios for the future.

\section{DEVELOPMENT OF A CIS TRADE REGIME}

The dissolution of the USSR in December 1991 put an end to the system whereby trade between the Soviet republics was essentially an internal, centrally planned regime. It also put an end to the numerous attempts to save the Union by transforming it into a confederative structure and a new-style economic community. ${ }^{15}$ Instead, there emerged twelve independent republics in charge of formulating their own foreign economic

\footnotetext{
${ }^{13}$ The primary focus here is on goods other than oil and gas. Although intra-CIS trade in energy represents a huge percentage, it tends to be subject to specific inter-state agreements with low transparency; see eg JR Dodsworth et al 'Cross-Border Issues in Energy Trade in the CIS countries', IMF Policy Discussion Paper 02/13 (2002); JP Stern The Future of Russian Gas and Gazprom (Oxford University Press Oxford 2005).

${ }^{14}$ We have compiled our own data-basis of multilateral and bilateral free trade agreements, other related trade agreements, and protocols, on the basis of different national (eg domestic legal data-basis, parliament and government web-sites) and international sources (eg World Bank, WTO). In principle, there is a difficulty in gathering agreements and determining their status not only in view of their large number but also because of inadequate notification to the CIS Executive Committee or the WTO. For example, only sixteen bilateral FTAs have been notified to the WTO by 22 November 2005 (<http://www.wto.org>).

${ }^{15}$ On the efforts for the restructuring of the Soviet Union, see E Walker Dissolution: Sovereignty and the Break-Up of the Soviet Union (Rowman \& Littlefield Oxford 2003).
} 
policies. In place of the USSR, the CIS was found as a loose and unstructured international regime.

One of the declared goals of the new organization was to maintain the pre-existing economic unity while placing inter-state relations on the basis of respect of sovereignty and mutual benefit. ${ }^{16}$ Nonetheless, the immediate focus was on dealing with the consequences of the 'civilized divorce' and investment in the institutional structure of the organization was not on the agenda. Furthermore, it became clear that the new CIS member states differed significantly in their views on this new style unity exactly as they differed in their initial attitude to independence and the perceptions of their ability to fair economically outside the common economic space of the USSR. As commentators note, during the course of 1992 and the beginning of 1993 Russia’s main concern was improving the relations with the West and focusing on domestic reform; in this context, many of the former Soviet republics were often seen as a burden to Russia’s economy. ${ }^{17}$ The rest of the CIS member states were preoccupied with domestic economic and political issues and the consolidation of their newly won (eg Georgia, Ukraine) or thrust upon them (eg most of the Central Asian countries) statehood. ${ }^{18}$ The newly independent states recognised their economic interdependence, their dependence on Russia in

\footnotetext{
${ }^{16}$ See Statement of The Governments of Russia, Belarus, and Ukraine of 9 December 1991 'On the Coordination of Economic Policy’, (1991) XLII:49 The Current Digest of Soviet Press 10.

${ }^{17}$ L Jonson Vladimir Putin and Central Asia (Taurus London and New York 2004) ; A Rahr 'Russia' in V Tolz and I Elliot The Demise of the USSR: From Communism to Independence (RFE-RL London 1995).

${ }^{18}$ For more on the Central Asian states, see eg MB Olcott Central Asia's New States: Independence, Foreign Policy and Regional Security (Carnegie Endowment Washington DC 1996), on Belarus and Ukraine, see eg A Tsyganko Pathways After Empire (Rowman and Littlefield Oxford 2001).
} 
particular, ${ }^{19}$ yet their policies towards the CIS reflected the weakness of domestic institutions and a suspicion towards a potential new centralization with Russia at the helm.

It is not surprising, then, that the main thrust of economic agreements of this early period, especially in view of the dramatic decline in production, was the partial preservation of the regime ancienne: that is the inherited from the planned economy system of deliveries (or barter) between enterprises. The system entailed preparing lists of goods to be exchanged between states, which diminished in length over time. It covered primarily raw materials, energy, machinery and foods, subjecting them to quotas and licensing requirements. ${ }^{20}$ The institutional model followed, namely the conclusion of a set of annual multi- and bilateral so called 'trade and cooperation agreements', and the provision of some multilateral rules, ${ }^{21}$ replicated largely the CMEA system.

Regarding the commodities outside the deliveries system, initially mainly consumer goods representing a small percentage of total trade, ${ }^{22}$ countries sought to 'normalize' relations by setting up a customs union. In March 1992, the Agreement on the Principles of Customs Policy was concluded which made provisions for free trade between its

\footnotetext{
${ }^{19}$ All successor states had a balance of payments deficit with Russia. The currency union existing until 1993 allowed the deficit countries to pay for these deficits in the common currency, the rouble, thus passing on the costs to the Russian monetary authorities. See B van Selm The Economics of Soviet Break-up (Routledge 1997).

${ }^{20}$ C Michalopoulos and D Tarr (eds) 'Trade in the New Independent States' (The World Bank Washington DC 1994); MB Olcott et al (n 2) 43- 45.

${ }^{21}$ Eg agreements providing for uniform contract terms and dispute resolution mechanisms for dealings between enterprises in realizing the deliveries. Agreement on the General Conditions of Supply of Goods between CIS Organizations of 20 March 1992, Convention on Resolving Disputes Arising from Economic Activities of 20 March 1992.

${ }^{22}$ M.B. Olcott et al (n 2) 38-39.
} 
signatories and for the adoption of a common external tariff. It also set up a special body, the Customs Council, with the task to coordinate the implementation of the customs union. This agreement, however, failed to produce an effect: some of the CIS countries did not sign it at all (Georgia, Azerbaijan and Ukraine), others signed it but did not ratify it (eg Russia), and it ultimately remained without real consequence for the rest. ${ }^{23}$ Instead, Russia proceeded to promote the conclusion of bilateral free trade agreements (FTA) with each of the CIS member states. Thus, in this initial period a hub-and-spoke relationship with Russia as the 'hub’ was established, with very few FTAs concluded between the rest of the 'spokes'. ${ }^{24}$

A new step in the trade relations between the CIS countries was made in the context of the Russian initiative for the formation of an economic union inaugurated with the Treaty on the Economic Union (TEU) of September 1993. This project reflected the change in Russia's foreign policy of the spring of 1993 in response to domestic criticisms, towards its 'near abroad' sphere and the promotion of Russia's image as the centre of CIS integration. ${ }^{25}$ The TEU was a framework treaty providing for a multilateral free trade association as the first step (to be followed by a customs union) in the progressive achievement of a European Union-style economic integration. More specific provisions in the implementation of this project were made in April 1994 with the conclusion of the Agreement on the Free Trade Area (1994 FTA). Importantly, the effort

\footnotetext{
${ }^{23}$ It was ratified by four countries only, and even by them with a significant delay when the agreement was arguably hardly relevant anymore.

${ }^{24}$ We have found such FTAs (we do not mean here the 'trade and cooperation agreements' on which the deliveries were based) concluded between Ukraine and Belarus, and Belarus and Moldova. We use the term 'hub-and-spoke' in a figurative sense rather than its common meaning in the aviation industry.

${ }^{25}$ L Jonson (n 17) 44.
} 
was made to embed the whole FTA project in a regional institutional framework. Some strengthening of the organization's structure had already taken place with the adoption of the Charter of the CIS of January 1993. In addition, a specialized permanent executive, the Inter-State Economic Committee, was set up with powers related to the coordination of economic cooperation. ${ }^{26}$ In the same spirit, attempts were made to strengthen the role of the Economic Court of the CIS, as it will be discussed further below.

The 1994 initiative (as well as the economic union project pioneered with the TEU), however, failed to create a multilateral free trade area. The agreement was signed by all CIS member states and was ratified by most. Yet, Russia's lack of ratification proved to be critical. Despite the rhetoric of economic integration, the Russian government was reluctant to proceed with what in effect were costly economic obligations under the agreement. $^{27}$ None of the administrative-style measures undertaken in 1997-1998, among which the appointment of the Russian magnate, Boris Berezovsky, as the executive secretary of the CIS, helped in revamping the multilateral project. Instead, Russia increasingly adopted a more pragmatic course of variable policies with regard to the different CIS countries and an emphasis on bilateral relations. ${ }^{28}$ As a part of this variable policy approach, Russia promoted the conclusion of a customs union with Belarus in January 1995, joined by Kazakhstan later that month, by Kyrgyzstan in 1997, and by Tajikistan in 1998. Behind this sub-regional initiative was an impulse for deeper

\footnotetext{
${ }^{26}$ Agreement on the Creation of the Inter-State Economic Committee of 21 Oct 1994.

${ }^{27}$ Particularly telling are Yeltsin's words of February 1994: 'Integration must not bring harm to Russia itself or lead to overstretch of our forces and resources, material as well as financial', quoted in L Jonson (n 17) 44. Furthermore, as Jonson notes, despite the general consensus on the strategic vision of Russia as a great power in the CIS region, no such agreement was in place regarding the specific measures to achieve this vision.

${ }^{28}$ That was particularly the case after the arrival of Yevgenii Primakov as foreign minister in January 1996.
} 
economic integration than CIS-wide developments. ${ }^{29}$ At the level of multilateral CIS initiatives, Russia supported primarily specific-issue agreements, such as the ones adopted on transit, customs formalities, re-export, or harmonization of customs legislation.

As far as the rest of the CIS (other than Russia) are concerned, arguably the 1994 FTA impulse created a momentum for the conclusion of bilateral FTAs among them. ${ }^{30}$ Thus, increasingly the hub-and-spoke FTA pattern of the early 1990s began to break up. Furthermore, with the strengthening of domestic institution-building and the advancement of national preference-formation, many CIS member states began seeking ways of reducing their political and economic dependence on Russia through the formation of sub-regional coalitions and the pursuit of balancing games with other strategic geopolitical partners. Thus, in 1994 Kazakhstan, Kyrgyzstan and Uzbekistan set up a Central Asian Economic Union, joined in 1998 by Tajikistan. ${ }^{31}$ Similarly, Georgia, Ukraine, Moldova, and Azerbaijan formed their own organization (GUUAM) in 1997, which Uzbekistan joined in 1999.

In April 1999 another effort was made to provide for a regional free trade area with the signing of a Protocol amending the 1994 FTA (1999 FTA). The 1999 Protocol reflected the changed circumstances in the relations between the CIS countries and reduced the economic cooperation agenda to free trade, eg the references to the free trade

\footnotetext{
${ }^{29}$ See Agreement on Deepening Integration in the Economic and Humanitarian Areas of 29 March 1996 and Treaty on the Customs Union and the Single Economic Space of 26 Feb 1999.

${ }^{30}$ Some of the bilateral FTA make an explicit reference to the 1994 FTA impulse, eg the 1995 GeorgiaUkraine FTA.

${ }^{31}$ In 1998, the organization was renamed to Central Asian Economic Cooperation and in 2002, to Central Asian Cooperation Organization ('CACO’). Russia joined CACO in 2004.
} 
area as a transitional step to a customs union were repealed. At the same time, still intent on investing into the regional project, an accompanying reform in the CIS multilateral institutions was undertaken, eg a new special body, the Economic Council was set up to ensure the implementation of the agreements and decisions related to the formation and functioning of the free trade area. An overhaul of many specific issue multilateral agreements was also undertaken.

Yet, despite these measures, despite even the pronounced completion of the creation of legal framework for free trade in $2003,{ }^{32}$ the relations between the CIS countries are still short of realizing the benefits of an effective free trade area. Russia's de facto post1994 position has changed little in its emphasis on bilateral relations and specific-issue multilateral agreements. As far as more general CIS-wide undertakings are concerned, Russia's position remains ambiguous. ${ }^{33}$ This is less so as far as sub-regional groupings are concerned. Russia has continued investing in the customs union with Belarus, Kazakhstan, Kyrgyzstan and Tajikistan, which was transformed into a fully-fledged regional organisation, the Euro-Asian Community (EAC) in 2000. Similarly, it entered CACO in 2004, contributing to its merger into the EAC in January $2006 .{ }^{34}$ Importantly, a new sub-regional grouping was set up with Ukraine’s participation, namely the Single Economic Space (SES) of 2003. ${ }^{35}$

\footnotetext{
${ }^{32}$ Statement of the CIS Council of Heads of State of 19 Sept 2003.

${ }^{33}$ In March 2005, for example, President Vladimir Putin stated that: '...the CIS never had any supertasks (sverkhzadach) of an economic nature, any integration tasks in the sphere of economics', available at: $<$ http://www.kremlin.ru/text/appears/2005/03/85912.shtml>. This statement was actively smoothed over by senior members of the Russian government.

${ }^{34}$ In this way Uzbekistan also became a member of EAC, see<http://www.evrazes.com>.

${ }^{35}$ The SES is an initiative of Russia, Belarus, Kazakhstan and Ukraine, see<http://www.eepnews.ru>.
} 
Finally, it needs to be noted that parallel to the efforts to engage in regional cooperation, there has been the process of the CIS member states' gradual endeavour to enter the WTO (We give an overview of CIS applications to the WTO in Table 1). Working parties commenced meetings particularly after 1995 and continued with varying degree of intensity. Four of the CIS countries, namely, the Kyrgyz Republic, Moldova, Georgia and Armenia have already entered the organization; the others (except for Turkmenistan) have applied for membership and many have reached fairly advanced stages in the market access negotiations and adoption of the WTO acquis. As studies of trade policies and practice suggest, the implementation of commitments and the realization of the advantages of WTO membership in the four current members, however, are far from certain. ${ }^{36}$ It has also been argued that regional cooperation in the CIS can become a useful vehicle in maximizing the benefits of participating in the WTO framework. We are unable to pursue in this work the full implications of the simultaneous pursuit of the global multilateral and regional routes for cooperation of the CIS countries. Yet, this overlap, as we will argue, has had important implications in affecting the development of the institutional framework for trade in the CIS.

It can be seen that several overlapping routes for trade cooperation in the CIS have been pursued. The sub-regional cooperation within the CIS has clearly become important both politically and in practical terms. Yet, this is not to the exclusion to bilateral relations; indeed new bilateral FTAs continue to be concluded. Furthermore, except for

\footnotetext{
${ }^{36}$ World Bank ‘Georgia: An Integrated Trade Development Strategy’, Report No 27264-GE (2003), World Bank 'Kyrgyz Republic Country Economic Memorandum: An Integrated Strategy for Growth and Trade' Report No 29150-KG (2004), World Bank ‘The Republic of Moldova: Trade Diagnostic Study’, Report No 30998-MD (2004).
} 
the EAC, none of the other regimes (SES or GUUAM) have yet given enough proof of their potential viability institutionally or at the level of economic cooperation. ${ }^{37}$ As far as the multilateral regime is concerned, despite the clear signals for (yet another) pending restructuring in the post-'colour' revolutions world, there is no evidence that trade cooperation in particular has been taken off the agenda.

Thus, in our analysis we focus on the legal and substantive characteristics of the institutions developed at the bilateral and multilateral level. The emphasis of the discussion is on the following documents operational at present:

- The bilateral agreements on free trade concluded since 1992 represented in our sample (Table 2);

- The multilateral 1999 FTA. We note the solutions embodied in the 1994 FTA in showing the evolution of the free trade regime. We also make references to some other general agreements (the 1992 Customs Policy Agreement and the 1993 TEU) in pointing to some institutional patterns (Table 3).

- The specific-issue multilateral agreements bearing on free trade (Table 3). In this category we also include certain acts adopted by the bodies of the CIS, as will be explained below.

\section{Sources of THE CIS TRADE Regime}

\section{A. Legal nature and specific features}

\footnotetext{
${ }^{37}$ On SES, see the report of LSE and Eurasia Heritage Foundation 'Single Economic Space: Viability, Implications, Prospects' (2005), at <http://www.eurasianhome.org/doc_files/lse_ses>.
} 


\section{a. International agreements}

Since the dissolution of the USSR, the relationships between the CIS member states have been based on the international agreements - bilateral or multilateral - concluded between them. ${ }^{38}$ Thus, it is the international law of treaties and the mechanisms for their transformation into the respective domestic legal orders that come to determine the legal nature of the CIS trade regime. In principle, all CIS member states (except Azerbaijan) are parties to the 1969 Vienna Convention on the International Law of Treaties and have dealt with the status of international law domestically in their Constitutions and laws on treaties. $^{39}$ In addition, a number of qualifications need to be made in the CIS context, which assume particular importance with regard to the multilateral agreements.

Firstly, an important element of the CIS framework is the so called 'interested party' principle. It implies that a state could choose not to participate in a certain agreement or a decision without this affecting its validity. ${ }^{40}$ The rule applies to all aspects of CIS cooperation thus, reserving no core areas to which all member states are required to sign up. This is even the case with regard to the agreements setting up the different bodies of the organization. Indeed, as Table 3 shows, many of the multilateral agreements signed to date have different numbers of signatories. While it is often CIS-sceptics like Georgia or increasingly autarkic countries like Turkmenistan that have abstained from signing agreements, the list is not limited to them as far as certain sensitive issues are concerned

\footnotetext{
${ }^{38}$ Art 5 of the CIS Charter adopted 22 January 1993.

${ }^{39}$ WE Butler The Law of Treaties in Russia and CIS (Cambridge University Press Cambridge 2002).

${ }^{40}$ Art 3 of the Temporary Agreement of 30 December 1991, Art 23 of the CIS Charter.
} 
(eg indirect taxation for Russia). On the one hand, the application of this principle allows each member state to construct for itself a regime that corresponds best to its interests. On the other hand, the lack of even a minimum set of instruments which member are required to join works against the logic of common commitment needed for robust regional economic integration. As far as the agreements setting up the organization's bodies are concerned, the result is problems with their legitimacy, including some practical (eg budgetary) concerns. ${ }^{41}$

Secondly, as in other areas of cooperation, many of the CIS multilateral agreements related to trade have been signed under reservations. Reservations are a legitimate international law instrument used to limit the binding effect of agreements with regard to the party that makes them. Their application is governed by the rules of the 1969 Vienna Convention on the International Law of Treaties and by some CIS documents. ${ }^{42}$ The Ukraine, for example, has used reservations to multilateral specific-issue agreements to disassociate itself from the possibility of being brought in front of the Economic Court of the CIS. ${ }^{43}$ Yet, as the Economic Court has noted many of the reservations made have a questionable legal validity. ${ }^{44}$ Belarus' reservation to the 1992 Customs Policy Agreement, for example, amounts to a broad escape clause to the main purpose of the agreement, namely the creation of the customs union. The 1994 and 1999 FTA attempt to

\footnotetext{
${ }^{41}$ These problems are particularly pronounced in the case of the Economic Court, see G Simonian ' $\mathrm{K}$ voprosu o priznaniia iurisdiktsii Ekonomicheskogo suda SNG (2000) 4 Moskovskii zhurnal mezhdunarodnogo prava 104-111; G Danilenko 'The Economic Court of the CIS' (1999) 4 NYU Journal of International Law and Politics 893-918.

421996 Procedural Rules of the Council of Heads of State and Government

${ }^{43}$ Eg Agreement on the Procedure for Customs Treatment and Customs Control of Goods of 8 Oct 1999.

${ }^{44}$ Advisory Opinion of the Economic Court of 15 May 1996, published in E Lauterpacht and J Greenwood (eds) International Law Reports, No 127 (Cambridge University Press Cambridge 2005).
} 
deal with the issue and to strengthen the mutual commitment by prohibiting reservations (Article 22). ${ }^{45}$ Yet, this did not prevent the Ukraine from expressing a reservation to Article 22.

Thirdly, another characteristic feature of the CIS multilateral formula is the preference for the conclusion of a large number of international agreements - framework or general agreements as well as more specific-issue ones - as opposed to the adoption of a limited number of comprehensive, detailed agreements. In the area of trade, in particular, there are the general provisions of Articles 4 and 5 of the 1993 Treaty of the Economic Union, the 1994 FTA amended with the 1999 Protocol, and the various specific issue multilateral agreements (Table 2). While this approach differs from choices made in other regional settings like NAFTA, it is not unknown in international trade cooperation, most notably in the case of the WTO.

On the one hand, it can be argued that this method adds to the flexibility in an organization in a number of ways. It allows it to pursue a project by gradually building consensus for subsequent steps - particularly important in a setting with a pronounced diversity of members, such as the CIS. ${ }^{46}$ In combination with the interested party principle, it also means that parties have a greater possibility to pick and mix with reference to their differing sensitivities and concerns, while keeping the whole project on course. Certain countries, such as Turkmenistan or Uzbekistan, have found it easier to sign some of the early general agreements, but have refrained from undertaking more specifically binding ones. Others, such as Ukraine, have refused to sign general (and

\footnotetext{
${ }^{45}$ Similarly, Art 8 (7) prohibits reservations to the 2000 Protocol on Import Licensing.

${ }^{46}$ Dragneva (n 10).
} 
often more sweeping in their objectives) agreements (eg the Treaty on the Economic Union) but have been willing to sign the detailing ones (eg the FTAs).

On the other hand, the fragmented multilateral regulation of one issue area (trade cooperation in this case) poses a greater danger of rule clashes, patchy implementation, and can lead to a non-transparent and complex to administer regime. It certainly creates the need for effective regional institutions for interpretation and dispute resolution, as it will be argued below, and presents significant demands on domestic institutions in ensuring compliance.

Finally, the founding documents of the CIS refer to both multilateral and bilateral agreements as instruments for cooperation. No exclusive choice is made in favour of either route and no guidance is given as to the way they should relate to each other. As our discussion shows, in the area of trade cooperation both routes overlap. As a result there arises the question about the interaction of the bilateral and multilateral regimes, and about the legal devices that need to be put in place to deal with possible conflicts of applicable law arising from such an interaction. We address this issue more fully after examining the key aspects of the subject-matter of the regimes (Section IV).

\section{b. Decisions of the CIS bodies}

Given the institutionalization of the CIS as an international organisation, a number of its bodies have been granted the power to adopt decisions. The question, then, is about the legal importance of these decisions and the degree to which they can represent an independent regulatory source for the trade regimes discussed in this work. 
To start with, such bodies are the Council of Heads of State and the Council of Heads of Government, which were initially the only organizational structures within the CIS. The Councils have often been the forum within which international agreements have been signed. In addition, they can adopt their own decisions (apart from the procedural ones) by consensus. ${ }^{47}$ According to a number of CIS documents, these decisions become binding on the member states taking part in their adoption subject to the 'interested party' principle. ${ }^{48}$ The understanding of this provision becomes easier with the help of the distinction made by the Economic Court of the CIS of the different Councils' decisions between 'normative' and 'political'. ${ }^{49}$ The first category of decisions serves to approve draft international agreements or has the attributes of international agreements. Accordingly, their 'bindingness' on member states emanates from their due transformation into domestic law. Indeed, a number of such 'normative' decisions with effect on trade cooperation can be noted, such as those approving the 1993 and 2000 Rules of Origin. The political decisions as such do not have a direct bearing on the trade regime; yet, they serve to define the broader context of international cooperation. Moreover, the degree between the 'normative' and the 'political' can often be quite fuzzy in the CIS. ${ }^{50}$

\footnotetext{
${ }^{47}$ Temporary Agreement on the Council of Heads of State and Heads of Government of 31 Dec 1991, Art 23 of the CIS Charter.

${ }^{48}$ Art 12 of the Agreement on the Temporary Rules of the Councils of 15 May 1992, Art 20 of the Procedural Rules of the Councils adopted by a Decision of 17 May 1996.

491996 Advisory Opinion (n 44), also Decision on Case No 01-1/1-98 of 22 June 1998, published in Lauterpacht and Greenwood (n 44).

${ }^{50}$ Dragneva (n 10).
} 
Another set of CIS bodies able to adopt decisions bearing on trade are the specialized permanent executives endowed with powers in the area of economic cooperation. ${ }^{51}$ Such are the Inter-State Economic Committee (IEC), existing between 1994 and 1999, and the Economic Council, set up in 1999. In line with the short-lived impulse for an enhanced EU-style cooperation, the IEC was given the right to adopt executive (razporiaditel'nye) decisions in the area of transferred competence, and certain decisions were subject to adoption by qualified or weighed qualified majority vote. ${ }^{52}$ The set up of the Economic Council, however, reverted back to the requirement for consensus in the adoption of its decisions. $^{53}$ Presently, the most important tasks of the Economic Council relate to preparing draft international agreements in the area of trade cooperation to be approved by the Councils of Heads of State and Government as the senior councils and signing agreements upon referral from them.

Finally, a number of branch cooperation organs (organy otraslego sotrudnichestva) with powers related to trade cooperation have been set up on the basis of separate, specific-issue agreements. Here we would mention two such organs. One is the Intergovernmental Council on Standardisation, Metrology and Certification, set up on the basis of an agreement of 13 March 1992, which consists of chiefs of the respective national services. ${ }^{54}$ The Committee is charged with important decision-making powers

\footnotetext{
${ }^{51}$ Here we do not mean the general permanent executive of the organization - Coordination and Consultative Committee, set up in 1993, and the Executive Committee which replaced it and the IEC in 1999; for more on the system of organs of the CIS see Dragneva (n 10).

${ }^{52}$ Art 10 of the Statute of the IEC, adopted as an appendix to the Agreement on the Creation of an IEC of 24 Oct 1994.

${ }^{53}$ Statute of the Economic Council, approved by a Decision of the Council of Heads of State of 25 Jan 2000.

${ }^{54}$ For more on the Council, see $<$ http://easc.org.by>.
} 
related to the harmonization of CIS standards and their adaptation to international requirements. It can submit drafts of agreements to be approved by the senior Councils or adopt them upon referral. ${ }^{55}$ These documents are adopted by consensus and have the status of interstate agreements.

Another body, the Council of the Heads of Custom Services, was set up in December 1993 as a part of the Economic Union impulse. At the time, the Council was entrusted with powers related to the coordination of customs policies and the work of national customs services, the harmonization of customs legislation, and the preparation of the common customs tariff for the attainment of a customs union. It could submit drafts to the senior Councils and prepare recommendations for the unification of customs documentation. ${ }^{56}$ The status of the Council was revised in 2002 and the scope of its powers was reduced in line with the mitigated agenda for economic cooperation in the CIS. Significantly, however, within its remaining competence the Council was given the power to decide by a $3 / 4$ majority of the interested parties voting. ${ }^{57}$

Thus, while there has been some delegation of decision-making powers in the CIS, it has ultimately taken place with the least sovereignty costs: the interested party principle applies, most decisions are taken by consensus and have the status of international agreements in terms of their bindingness on the member states. Furthermore, the organizational system created has often been criticised for its lack of inner coherence and

\footnotetext{
${ }^{55}$ Regulation (Polozhenie) of the Interstate Council adopted as an appendix to the Protocol of 20 June 2000 1992 Amending the 1992 Agreement on Standardization, Metrology and Certification.

${ }^{56}$ A number of important agreements have been drafted, see $<$ http://www.ec-cis.org/main.aspx?uid=2538 $>$.

${ }^{57}$ Regulation (Polozhenie) approved by a Decision of the Council of Heads of Government of 30 June 2002.
} 
inefficiency ${ }^{58}$ During the late 1990s a number of efforts were undertaken to streamline the system, in particular to ensure the coordination of the numerous branch organs with the executive centre, as well as to strengthen the primacy of the senior councils within the organization. Despite these attempts, however, serious coordination problems remain likely in this area.

\section{B. Transformation into domestic law}

As already noted, the agreements concluded within the CIS and the acts of CIS bodies take legal effect domestically after a due process of transformation into national law. We are unable, in this article, to examine fully the extent and the effectiveness of this transformation. ${ }^{59}$ We find it important to note, however, some of the key domestic provisions in this respect because of the prominence they have been given in CIS debates on the free trade regime. ${ }^{60}$

The first issue relates to the problems of ratification of the large number of agreements. ${ }^{61}$ The uneven or delayed ratification, or lack of such, has been perceived as a significant obstacle to integration. As Table 3 shows, the problem concerns both general multilateral agreements (eg Kyrgyzstan's ratification of the 1992 Customs Policy

\footnotetext{
${ }^{58}$ Eg G Shinkaretskaia 'SNG: tendentsii razvitiia' (1993 - 1994) Rossiiskii ezhegodnik mezhdunarodnogo prava $78-100$. The arguments made in this early publication, we believe, are still valid today.

${ }^{59}$ For more on the general problems of implementation of international law in the CIS, see G Danilenko 'Implementation of International Law in CIS States: Theory and Practice' (1999) 10 European Journal of International Law 51-69.

${ }^{60}$ The issue has been of a particular concern of the Inter-Parliamentary Assembly of the CIS as successive documents and statements in its publication Vestnik Mezhparlamentskoi Assamblei show.

${ }^{61}$ Most CIS legal systems require the ratification (as opposed to cases when the signing or confirmation of an agreement is sufficient) of important trade-related international agreements, yet there are differences in the provisions of the law of treaties of the CIS countries. Butler (n 39), Dragneva (n 10).
} 
Agreement only in 1999, or Georgia’s ratification of the 1994 and 1999 FTA in 2003) and specific-issue agreements (eg Ukraine's ratification of the 1994 Customs Cooperation Agreement in 2000). Russia's position on the general multilateral agreements has proved to be of particular importance. Regarding the 1992 Customs Policy Agreement, after delaying the ratification for a decade, Russia announced in 2003 that it will not participate in the agreement. Regarding the 1994 and 1999 FTAs, Russia's signals have been more controversial. On the one hand, Russia has not ratified these agreements to date. On the other hand, it agreed to apply them temporarily in advance of ratification; $^{62}$ it signed and ratified closely-related agreements, and a number of agreements and statements it participates in make specific reference to the general FTAs. The ratification of bilateral agreements has generally been less problematic, although in some cases it has also taken a long time. ${ }^{63}$

A further important issue relates to the constitutional status of international law in domestic legislation. Following the doctrine of 'monism' CIS countries provide that agreements which have been duly signed and transformed into national law, assume an obligatory role within the country. In doing so, most of them envisage an express provision whereby the norms of international law are made a (integral) part of the domestic legal orders. Yet, the scope of international law for these purposes is defined differently. The Russian Federation adopts the broadest formulation, referring to

\footnotetext{
${ }^{62}$ Art 23 of the 1995 Russian Law of International Treaties allows temporary application of international agreements but requires that they are submitted to the Russian parliament (the Duma) within a period of no more than six months from the date of the commencement of the provisional application. Given the lack of ratification (or other decision) on the FTAs, interesting constitutional issues are raised, which we are unable to explore in this work.

${ }^{63}$ Eg the 1992 Belarus - Ukraine FTA was ratified by the Ukraine only in 1999, similarly the 1994 Ukraine - Kazakhstan FTA was ratified by the Ukraine in 1998.
} 
international treaties and generally-recognized norms and principles of international law. Other countries include only international treaties in general (Azerbaijan, Georgia, Tajikistan), or ratified international treaties in particular (Armenia, Kyrgyzstan, the Ukraine). The remaining CIS members, that is Belarus, Kazakhstan, Moldova, Turkmenistan and Uzbekistan do not envisage such a provision.

Further, all the CIS countries except Kyrgyzstan and Uzbekistan contain (a) specific provision(s) in their Constitutions and/or Law on Treaties on the prevalence of international treaties over inconsistent norms of domestic law, subject to different conditions. ${ }^{64}$ In addition, some countries (Russia, Georgia, Kazakhstan, Kyrgyzstan and Tajikistan) expressly envisage provisions on the direct effect of certain international agreements (the so called 'self-executing' agreements). ${ }^{65}$ Yet, not many of the CIS agreements under discussion would satisfy the requirements to be qualified as selfexecuting. Finally, all CIS countries' Law on Treaties contain provisions reproducing the principle of pacta sunt servanda. They envisage also the duty of state agencies to comply with international treaties and ensure the fulfilment of obligations ensuing from them.

\section{SUBSTANCE OF BILATERAL AND MULTILATERAL REGIMES}

\section{A. Scope of commitment}

\footnotetext{
${ }^{64}$ Butler (n 39).

${ }^{65}$ Art 5 of the Russian Law of Treaties and Art 4 of the Tajik Law of Treaties define 'self-executing agreements' as those which are officially published and do not require implementing acts; Art 12 Paragraph 3 of the Kyrgyz Constitution refers to ratified international treaties; Art 4 Paragraph 3 of the Kazakh Constitution - to ratified international treaties which do not require a promulgation of a law for their application; Art 6 Paragraph 2 of the Georgian Law on Treaties - to officially published agreements, establishing right and duties of a specific character and not requiring a clarifying normative act.
} 
The bilateral and the multilateral FTAs and related specific-issue agreements (Tables 2 and 3) share many similarities in terms of the substance and scope of commitment undertaken by their signatories. Yet, the multilateral regime tends to be generally more ambitious. We compare the two with reference to market access undertakings, rules, and other trade-related commitments.

\section{a. Market Access Undertakings}

Both the bilateral and the multilateral FTAs aim to remove barriers to trade among their signatories and contain a general rule to that effect. All agreements include tariffs and other measures with equivalent effect in that rule. The early bilateral FTAs, however, exclude quantitative restrictions, providing only for 'refraining' from their adoption within the general framework of contingent protection. ${ }^{66}$

Further, both regimes allow for exemptions from the free trade of goods, which are to be traded on a MFN basis. Yet, there is a difference in the obligation of the signatories regarding the elimination of these exemptions. The bilateral agreements set up a free trade area with exemptions to be agreed by the parties in special protocols, representing an inseparable part of the agreement. Some agreements provide for a specific period, within which the protocols are to be adopted. Importantly, most agreements do not explicitly mention the goal of gradual elimination of existing exemptions. ${ }^{67}$

\footnotetext{
${ }^{66}$ Some agreements, such as the 1995 Georgia-Ukraine FTA even omit this rule.

${ }^{67}$ The only bilateral agreement which we have found to mention progressive elimination is the 1993 Ukraine-Russia FTA.
} 
The 1994 FTA also refers to exemption protocols, yet it goes further than the bilateral FTAs by specifically referring to scheduled elimination of the exemptions. ${ }^{68}$ It envisages a six-month deadline for the adoption of a single list of exemptions. Until the adoption of such a single list, the existing bilateral exemption protocols should be applied.

The language of the 1999 FTA is more explicit than the 1994 FTA with regard to the elimination undertaking - it requires that new bilateral protocols are concluded within a twelve-month period with the purpose of agreeing schedules for the gradual elimination of existing exemptions. It also provides specifically that signatories should not introduce any barriers in addition to the ones agreed in earlier bilateral documents. ${ }^{69}$ In line with this framework, in December 1999 the Economic Council also adopted a Protocol on Progressive Elimination of Exemptions, which aims to spell out a common procedure for the negotiation of the bilateral elimination protocols, including a special conciliation procedure in the event of a dispute.

Thus, in terms of market access commitments, the multilateral framework incorporates the bilateral approach. Yet, it seeks to subject it to a common procedure and to strengthen the elimination commitment. In principle, not all bilateral agreements and protocols envisage tariff exemptions. ${ }^{70}$ For those which do, the effects of the multilateral initiative are not obvious. It has been argued that, generally, the percentage of exempted

\footnotetext{
${ }^{68}$ Art 3.

${ }^{69}$ Art 3 Paragraph 2.

70 For more on the exemptions maintained, see the information of the CIS Executive Committee at <http://www.ec-cis.org/main.aspx?uid=1136>, as well as UNECE (n 5). The latter report also discusses the empirical difficulties in obtaining accurate information on the subject.
} 
goods is small and restricted to 'sensitive' products such as sugar, alcohol and tobacco. ${ }^{71}$ Yet, given that the commodity groups subject to free trade are not clearly set in advance but left to protocols, there remains the potential for frequent revisions and uncertainty, as commentators have noted. ${ }^{72}$ In terms of the progressive elimination of these exemptions, new protocols have not been concluded within the twelve-month period agreed upon. Indeed, the negotiations have been slow and complicated. Russia, for example, has used its bargaining superiority to condition its negotiations on exemptions on the resolution of the sensitive issue of VAT. ${ }^{73}$ The latest results envisage that existing exemptions be eliminated by $2012 .^{74}$ Some countries, such as the Ukraine, however, have refused to sign under the 2012 schedule in an attempt to exert pressure (with little obvious effect) for an earlier resolution by Russia. ${ }^{75}$

\section{b. Other FTA rules}

\footnotetext{
${ }^{71}$ Eg address of the Russian Minister of Economy and Trade German Gref to the Russian Parliament of 26 February 2003, quoted in Freinkman et al (n 4) 46. The information of the CIS Executive Committee (n 70) refers to exemptions being between $0.1-0.2 \%$ of mutual import and $0.24-0.36 \%$ of mutual export in 20012002.

${ }^{72}$ Freinkman et al (n 4) 45-46.

73 See Information on the Progress and Results of Bilateral Negotiations on Exemptions from Free Trade and the Transition to the Principle of Destination in Indirect Taxation, adopted by a Decision of the Council of Heads of Government of 31 May 2001, at <http//:www.garant.ru>.

74 See reports on the meeting of the Council of Heads of Government of June 2005 in Tbilisi, $<$ http://pda.lenta.ru/news/2005/06/06/cis>.

${ }^{75}$ Free trade without exemptions remains the priority for the Ukraine within the SES too.
} 
What is meant here are several groups of rules directly related to the functioning of a free trade area, namely customs procedure and tariff classification of goods, rules of origin, standards and technical requirements, safeguards and special protection measures.

Firstly, with regard to the tariff classification of goods both bilateral and multilateral FTAs refer to the application of a 9-digit Common Customs Nomenclature based on the Harmonized System and the Combined Customs Tariff of the EC. The FTAs provide further for the possibility for each country to introduce a 10th digit for its own purposes. The multilateral FTAs envisage that the commodities nomenclature will be maintained through Russia's Customs Service and its representatives into the respective international organization. In addition, a special agreement of 3 November 1995 was concluded on the Single Commodities Nomenclature of the CIS, which provides for a role of the CIS Council of Heads of Customs Services in the management of the commodities nomenclature.

In terms of commitments related to customs procedures, the bilateral agreements provide only for the exchange of information on customs issues and customs statistics. In addition, selected countries have concluded specific bilateral agreements on customs cooperation. ${ }^{76}$ The multilateral framework is much further reaching. The 1994 and 1999 FTAs sets the goal of harmonization and simplification of customs procedures, and its Article 6 provides for the adoption of a single customs clearance form. In addition, a special Agreement on Customs Clearance and Customs Control was agreed in October 1999 on the same matter.

\footnotetext{
${ }^{76}$ Eg Russia and Kazakhstan, 28 March 1994, Russia and Uzbekistan, 2 March 1994.
} 
A second set of rules relates to the origin of goods for the purposes of customs treatment. The early bilateral agreements envisage a basic test for determining the origin of goods. Most of them also refer to a separate detailed document to be adopted on the matter. ${ }^{77}$ Such rules were adopted multilaterally in 1993 and amended in 2000. Indeed, the multilateral FTAs refer to those rules. Generally, the rules have been evaluated by international organizations as conducive to intra-CIS trade, especially in allowing cumulation of origin. ${ }^{78}$

Thirdly, rules on technical and product standards (sanitary and phytosanitary measures included), are another important area of FTA rules in general. Specifically for the CIS, its member states inherited the USSR system of standards. One of the early multilateral agreements provides for the recognition of the USSR standards (GOST) as international standards for the CIS countries, and for policy coordination in the area of standardisation, metrology and certification. $^{79}$ As noted earlier, a special Intergovernmental Council was set up to further this cooperation and develop new standards in line with international requirements. ${ }^{80}$ Pursuant to this agreement, member states recognise each others certificates of conformity and quality. Yet, as noted previously the CIS system does not deal fully with the issue as new national technical

\footnotetext{
${ }^{77}$ No such reference is made in the 1995 Kazakhstan-Kyrgyzstan FTA. Other agreements make a blanket reference to 'origin determined in accordance with international regulations', eg 1996 Georgia-Azerbaijan FTA or 1997 Georgia- Kazakhstan FTA.

${ }^{78}$ Eg Freinkman et al (n 4) 48-49.

${ }^{79}$ Agreement on Coordinated Policy in the Area of Standardization, Metrology and Certification of 13 March 1992.

${ }^{80}$ The Council was recognised by ISO as a regional organization under the name of Euro-Asian Council on Standardisation, Metrology and Certification in 1996.
} 
requirements and standards can be introduced without proper notification. ${ }^{81}$ At the same time, the distinction between mandatory requirements and voluntary standards established in international practice is beginning to be introduced only in the context of WTO (preparation for) accession.

In addition to the framework of the 1992 multilateral agreement, however, a number of bilateral agreements on cooperation in the field of metrology, certification and standardization were also concluded in the period 1993-1994. ${ }^{82}$

The early bilateral FTAs contain neither rules on technical requirements and standards, nor an explicit reference to the 1992 multilateral agreement. In contrast, the 1994 FTA contains a general rule in its Article 4, referring to the goal of harmonization of technical standards on a bilateral and multilateral basis. The 1999 FTA clarifies and expands the rule by providing for non-discrimination regarding technical requirements of goods originating in another member state, as well as providing for cooperation and exchange of information in the area of metrology, standardisation and certification with the purpose of eliminating technical barriers to trade. Accordingly, an overhaul of the existing framework was undertaken in 2000 amending the 1992 Agreement as well as the Rules of Procedure of the Interstate Council on Standardisation, Metrology and Certification. At the same time, a special Agreement on Technical Barriers was concluded in June 2000, which sought to incorporate some of the WTO principles and definitions.

\footnotetext{
${ }^{81}$ Freinkman et al (n 4) 49.

${ }^{82}$ Most of the agreements we have been able to find are with Russian participation and follow the same template.
} 
It is also worth noting that some of the most recent FTAs, such as the 2003 agreement between Ukraine and Moldova, refer to the application of the rules of the WTO regarding technical barriers to trade, and include sections on sanitary and phytosanitary measures.

Finally, as far as the provisions on general safeguards and special protective measures are concerned, there is a clear evolution of the regimes, particularly of the multilateral one. Most bilateral agreements contain two separate articles - one on general safeguards and exceptions, and another on special protective measures. General exceptions typically cover measures to safeguard concerns such as health, morals, natural resources and national security. They are imposed upon the judgement of the country that its vital interests are at stake or that they are unconditionally needed to fulfil international obligations, with no special notification required. The special protective measures (primarily in the form of quantitative restrictions and measures with equivalent effect) are allowed as a temporary protection, subject to the condition of remaining within reasonable limits and strictly defined periods of time. Some agreements add the requirement that they should seek to cause the least negative impact and be of exclusive nature. Regarding the specific circumstances in which such measures can be applied, the bilateral FTAs typically refer to: acute deficit of certain products domestically, acute balance of payment deficits, injury or threat of injury to domestic producers of competitive products, and preventing re-export. ${ }^{83}$ The majority of agreements post-1994 refer directly to the circumstances envisaged in GATT/WTO rules. ${ }^{84}$ Most agreements require that the party imposing the temporary measures provides the other party with full

\footnotetext{
${ }^{83}$ The early FTAs provide only for the first two circumstances.

${ }^{84}$ The 2003 Ukraine - Moldova FTA is most sophisticated in distinguishing different types of measures and making specific references to WTO rules.
} 
information and engages in consultations. Yet, a number of FTAs clearly confuse the two types of exemptions and the conditions under which they apply to the extent that the effectiveness of the respective provisions are put in doubt. ${ }^{85}$

The 1994 multilateral FTA contains an extensive clause (Article 13) on general exemptions and exemptions on grounds of security. It does not, however, envisage any rules regarding the application of special protective measures. In fact, it includes balance of payment and some other temporary economic concerns amongst the grounds for general exemptions with no conditions attached. In that they provide for a weaker discipline than that of the bilateral FTAs requiring a reasonableness test and temporary application. It only requires that a state should issue notifications on measures of foreign trade state regulation and is obliged to engage in consultations (Article 14).

The 1999 regime represents a clear, albeit limited, attempt for improvement to the 1994 FTA rules and is further reaching than the bilateral FTAs. The impulse coincides with a wave of protective measures, adopted particularly by the larger CIS countries like Russia, Ukraine or Kazakhstan, and leading to prolonged 'trade wars' between them. ${ }^{86}$ To start with, the 1999 FTA defines in rather broad terms quantitative restrictions and other measures with equivalent effect (Article 3.3). As far as the general exemptions rule is concerned (Article 13) it leaves the list of circumstances unchanged, but adds the requirement of the GATT regime that such measures should not be applied on an arbitrary or discriminatory basis. Most notably, it introduces a new Article 13a related to special protective measures in the circumstances of injury or threat of injury on a contracting party as well as dumped or subsidised imports leading to such an injury or a

\footnotetext{
${ }^{85}$ Eg The 1995 Ukraine and Georgia FTA.

${ }^{86}$ Eg World Bank ‘Ukraine Trade Policy Study’ Report No 29684-UA (2004).
} 
serious threat thereof. The provision seeks to define the material and procedural conditions for imposition of such measures (eg injury and the criteria for determining its existence). Further, it provides for a conciliation mechanism for resolving related disputes, which will be discussed further below.

\section{c. Trade related issues}

Under this heading we group a number of 'free trade plus' rules, which are increasingly becoming part of trade agreements world-wide.

Firstly, rules related to competitive market conditions. Most bilateral FTAs contain a rule related to avoidance of unfair trade practices and avoidance of abuse of dominant market position. The rule is envisaged in the 1999 multilateral FTA (Article 17a). The bilateral FTAs also envisage an undertaking to abstain from state aid in the form of subsidies leading to disruption of normal economic condition. The 1994 FTA refers to the same issue of export and other subsidies if they affect competitive conditions (Article 9). The 1999 regime takes the rule further by providing for the powers of the Inter-State Economic Committee (or its successor) to monitor the granting of subsidies other than those related to exports and develop rules for its regulation on the basis of international practice (Article 9.3). Finally, the 1999 FTA deals for the first time with public procurement in the context of liberalisation of national markets, requiring its application to be on a non-discriminatory basis (Article 17b).

Secondly, one of the most important trade related issues in the CIS is that of transit. Yet given the complexity of the issue, we mention it only in passing. Provisions on 
freedom of transit, non-discrimination and relations between transit fees and cost of actual services have been included in all bilateral FTAs. Similar rules are contained in the 1994 and 1999 FTAs (Article 10). In addition, a large number of special bilateral and multilateral agreements have been concluded which cover the same issues.

Thirdly, all bilateral FTAs provide for non-discrimination in the tax treatment of commodities originating in the territory of the other contracting party. The same rule is embodied in Article 8 of the 1994 and 1999 FTAs. The greatest sensitivities, however, occurred in relation to indirect taxation. At the beginning of the 1990s, CIS countries levied indirect taxes at source, following the principle of origin. Yet, problems occurred with the unilateral switch by some countries, such as Ukraine, to the principle of taxation at destination in line with international practice. The ensuing problems of trading with the ‘origin’ countries (eg Russia) were resolved through bilateral agreements. The promotion of a multilateral agreement was attempted in 1998, whereby the CIS countries were required to adopt the destination principle, requiring country of export to levy 0\% VAT or exempt from tax (and arrange for VAT refund). Importantly, however, Russia did not sign this agreement. The 1999 FTA in its Article 18 attempted to deal with the issue again. It provided, however, that the changes will be effective as of 1 January 2000 in conformity with national legislation. Despite its lack of ratification, Russia agreed to move to the destination principle on a strictly bilateral basis and, as mentioned earlier, subject to the introduction of exemptions to the FTA regime. The issue was only recently 
resolved: as of 1 July 2001 Russia applied the origin principle only with regard to oil, gas condensate and natural gas, and finally removed this exemption as of 1 January $2005 .^{87}$

Fourthly, none of the bilateral FTAs contain rules related to services. Both multilateral ones include only what can be termed as a 'best intentions' provision related to the gradual elimination of barriers to services (Article 17).

Finally, none of the agreements, except the 'new style' 2003 FTA between Ukraine and Moldova refer to intellectual property. Similarly, there are no provisions related to labour or environmental conditions.

\section{B. Strength of commitment}

In this section we discuss the bilateral and multilateral regimes in terms of their 'strength' or degree of bindingness. As noted earlier, both regimes rely on international agreements. In this sense, a system of legal remedies provided by international law applies in addition to any political means that can be adopted. Yet, there is a variety of devices which can be used in agreements to mitigate the bindingness of internationally undertaken commitments. $^{88}$ A particularly critical mechanism in ensuring the credibility of commitments relates to the choice and design of dispute-resolution bodies and procedures. $^{89}$

\footnotetext{
${ }^{87}$ Art 13 of the Federal Law No 118 On Entry into Force of Part II of the Tax Code of 5 August 2000. It should be noted, however, that Russia continues to levy an export tax on its energy exports.

${ }^{88} \mathrm{~K}$ Abbott et al 'The Concept of Legalization'(2000) 3 International Organization 401-419.

${ }^{89}$ See eg L Helfer and AM Slaughter 'Why States Create International Tribunals: A Response to Professors Posner and Yoo’, (2005) 93:3 California Law Review 899-956.
} 
The bilateral FTAs envisage no special mechanism for resolving disputes between its parties, other than negotiations. Few of them refer also to resolution through 'other means acceptable to the parties', but no further qualifications are made. ${ }^{90}$ A notable exception is the 2003 Ukraine - Moldova agreement which relies on a conciliation by an ad hoc working group when disputes are related to competition, state aid, and the imposition of special trade measures. ${ }^{91}$ While the FTAs set up bilateral commissions to facilitate the realization of the agreements, very few of these commissions are granted any explicit dispute resolution functions. ${ }^{92}$ Thus, in terms of their institutional set up, these agreements can be described as "first generation FTAs", ones that adopt a diplomatic model, common to trade agreements in the 1960s and 1970s in the West. ${ }^{93}$

By comparison, the multilateral agreements represent an attempt to strengthen the bindingness of the commitments undertaken. The most ambitious approach is demonstrated by the 1993 Treaty of the Economic Union, which provides for resolution of disputes through negotiations or bringing an action before the Economic Court (Article 31). In the event of failure of the above routes, the Treaty allows for the parties to turn to other international judicial bodies. ${ }^{94}$ Importantly, the Treaty attempts to strengthen the role of the Economic Court both in terms of its compulsory jurisdiction and the effect of

\footnotetext{
${ }^{90}$ Eg most of Kazakhstan's 1997 FTAs, or the 1994 Ukraine-Uzbekistan FTA.

${ }^{91}$ Art 26.

${ }^{92}$ The only exceptions we have found are the 1994 Ukraine-Kazakhstan FTA and the 1995 UkraineGeorgia FTA which provide for interpretative and dispute resolution powers of the commission. At the same time, few agreements do not even mention a commission, eg 1997 Kazakhstan-Belarus FTA and 1997 Kazakhstan-Uzbekistan FTA.

${ }^{93}$ Reich (n 8).

${ }^{94}$ On the other international judicial institutions available to CIS countries, see L Anisimov 'Mekhanizmy razresheniia sporov i predotvrashcheniia konfliktov mezhdu gosudarstvami-uchastnikami SNG' (2002) 1 Moskovskii zhurnal mezhdunarodnogo prava $97-115$.
} 
its decisions. ${ }^{95}$ The Economic Court was set up under a special Agreement of 6 July 1992 with the mandate of 'ensuring the uniform application of the agreements of the CIS and the economic obligations and contracts based on them. ${ }^{96}$ It was granted the power of resolving inter-state disputes of an economic nature, namely: 1) those related to the implementation of the economic obligations of the states, envisaged in agreements and acts of its organs, and 2) on the consistency between normative acts of the member states on economic questions and the agreements and other acts of the CIS. ${ }^{97}$ In addition, other disputes can be submitted to the Court when envisaged by an agreement, such as the 1993 Treaty of the Economic Union which brings conflicts over its application or interpretation under the Court’s compulsory jurisdiction.

According to the 1992 Agreement on the Court's Status, its decisions are nonbinding: they are only recommended for adoption by the country found in violation. ${ }^{98}$ If the party found in violation fails to comply with the Court's decision, the aggrieved party can only turn to the senior plenary body of the organization, the Council of Heads of State. ${ }^{99}$ Similarly, systematic breaches of obligations under agreements and decisions of the organs of the CIS can be submitted to the Council. The effect of such a submission, except for peer pressure and reputational damage, however, is uncertain. Given that Council decisions are taken by consensus, any unwanted action can be blocked by the interested party.

\footnotetext{
${ }^{95}$ For more on the general institutional features of the Court, see Danilenko (n 41), Dragneva (n 10).

${ }^{96}$ Art 1 . The role of the Court was affirmed by its inclusion amongst the institutions of the Commonwealth in the 1993 Charter.

${ }^{97}$ Art 3 of the Statute of the Economic Court of 6 July 1992.

${ }^{98}$ Art 3 paragraph 4.

${ }^{99}$ Art 9 of the 1991 Minsk Agreement, Art 17 of the CIS Charter.
} 
The Treaty on the Economic Union, however, attempts to add some 'teeth' to the Court's rulings by requiring that 'if the Economic Court recognizes that $[\ldots]$ a member state has not fulfilled an obligation ensuing from the Treaty, this state is obliged to take measures connected with the implementation of the decision of the Economic Court'. ${ }^{100}$ Similarly, it mentions the possibility for envisaging in future agreements sanctions for the failure to fulfill the obligations undertaken. Certainly according to the opinion of the Court, Article 31 amounts to an explicit undertaking by the TEU's signatories to be bound by its rulings. ${ }^{101}$

As mentioned earlier, however, the formula for integration proposed with the TEU proved to be very short-lived. Indeed, it is possible to see some departures from the above approach even in the 1994 FTA. Article 19 of the agreement provides for a sequence of measures: negotiations, conciliation, resort to the Economic Court, and resort to other international judicial procedures. The transition to each consecutive step can be made either by mutual consent, or by the request of the aggrieved party if no progress has been achieved within six months of the beginning of the procedure. The usage of the conciliation procedure is not restricted to a particular issue area, yet the provision for it is extremely minimal. The reference is only to the appointment of ad hoc working groups with the power to issue recommendations, and nothing on time-tables or group composition. In terms of the judicial forms of dispute-resolution, the resort to other international judicial bodies can clearly be used as an alternative route to that of the Economic Court. While the Economic Court itself has defended its primacy, ${ }^{102}$ a number

\footnotetext{
${ }^{100}$ Art 31 Paragraph 2.

${ }^{101}$ Advisory Opinion C-1/19-96 of 15 May 1997.

${ }^{102}$ Ibid.
} 
of specific issue multilateral agreements similarly mention the Court as an alternative route. $^{103}$

Finally, the 1994 FTA provides for some collective 'self-help' measures. If a party breaches of its articles with the effect of causing a serious damage to the objectives of the agreement, the other contracting parties can terminate the effect of the agreement (or some of its provisions) with respect to it or even exclude that party from the agreement. $^{104}$

The 1999 FTA and the package of documents related to it make two important provisions with regard to dispute resolution. Firstly, the 1999 FTA envisages special conciliation procedures in the areas of special trade measures (Article 19) and elimination of exemptions (1999 Protocol ${ }^{105}$ ). The Article 19 procedure includes consultations to be held within two-months of the request, followed by conciliation administered by a working group appointed on an ad hoc basis by the Executive Committee ${ }^{106}$ within thirty days of the request being made. No further details related to the procedure are specified, except for stating that the working group's decision is non-binding. If the conciliation fails, the FTA authorises the application of 'self-help' measures in the form of reciprocal and equivalent termination of the obligations of the aggrieved party under the agreement. The provision for conciliation procedure on elimination exemptions is similar, yet

\footnotetext{
${ }^{103}$ Art 11 of the 1998 Agreement of the Principles of Indirect Taxation, Art 15 of the 1999 Agreement on the Procedures for Customs Clearance and Customs Control.

${ }^{104}$ Art 25 Paragraph 2 of 1994 FTA.

${ }^{105}$ Protocol on the Rules of Procedure for Holding Consultations on Staged Elimination of Exemptions from the Free Trade Area, adopted by the Economic Council on 24 December 1999.

106 The 1999 FTA refers to the 1994 Inter-State Economic Committee. The Committee, however, were taken over by the Executive Committee of the CIS, set up in 1999. The latter's Statute, however, does not have an explicit provision to that effect.
} 
somewhat more detailed. If no agreement is reached as a result of the conciliation process, the dispute is ultimately brought to the Council of Heads of Ministers.

Secondly, the 1999 FTA departs from the prior approaches in avoiding any explicit reference to the Economic Court. It provides only that the requirement for engaging in consultations and conciliation procedures does not prevent the parties from resolving their conflicts 'through the procedures envisaged by international law' (Article 19.5). It is difficult to judge whether this vague language conceals a retreat from pursuing disputes through the Court or not. On the one hand, there has been dissatisfaction with the effectiveness of the Court and its lack of authority. Not many cases have been brought before the Court and nearly all of them relate to interpretation of CIS agreements or decisions rather than to inter-state disputes. ${ }^{107}$ In the words of one of the most prointegrationist politicians in the CIS, the Kazakh President Nazarbayev, 'nobody anyway pays any attention to the decisions adopted' by the Court. ${ }^{108}$ On the other hand, there have been a number of (failed) efforts to enhance the institutional profile of the Court, including extending its jurisdiction ever disputes brought by private parties in relation to the free trade area. ${ }^{109}$ A fresh initiative was announced at the summit of CIS Heads of

${ }^{107}$ During the first decade of the existence of the Court it has considered sixty five cases. The majority of them (fifty four) have resulted in advisory opinions interpreting agreements and decisions of the CIS; nine cases relate to disputes on non-performance of economic obligations of member states; two - to labour disputes, see<http://sudsng.org/about $>$. We do not have full information about the nine economic disputes and the effect of their decisions. It has been noted, however, that often they have been resolved through negotiations rather than compliance with the Court's judgement, I Fisenko, 'Praktika Ekonomicheskogo Suda SNG' (1997) 3 Moskovskii zhurnal mezhdunarodnogo prava 26 -33.

${ }^{108}$ Statement at the Council of Heads of State summit in Astana, 17 Sept 2004, reported in Rossiiskaia Gazeta of 17 Sept 2004.

${ }^{109}$ Eg the Decision of the Council of Heads of State 'On the Work of the Economic Court and on the Need for its Improvement' of 26 May 1995 and the Draft Concept of the Economic Court of April 1996 in 
State in August 2005. Judging by past experience with organizational reform in the CIS, however, the outcome of this latest initiative is highly uncertain. ${ }^{110}$

Thus, while providing more opportunities for dispute resolution than the bilateral FTAs, the effectiveness of the multilateral regime remains in question. It remains short of making provisions for a binding mechanism (judicial or based on ad hoc panels) along the example of effective regional organizations as well as the WTO. It provides for the setting up of a non-binding conciliation through ad hoc working groups, particularly important in the area of special trade measures, yet it fails to provide for the panel independence or for a sufficiently detailed procedure and time-table to guarantee the credibility of the process. In the ultimate, our observation is that it is through bilateral negotiations that disputes tend to be resolved rather than through resorting to the Economic Court, panel conciliation or even the framework of the Council of the Heads of State.

\section{Interaction of regimes}

Having discussed the substance of the bilateral and multilateral regimes, it is important to address the issue of their interaction. In principle, the overlap of several agreements dealing with the same subject-matter can result in either accumulation of norms

response to it. Similarly, the Draft Protocol Amending the Status of the Economic Court of 3 December 1999 prepared by the Court and the Concept Paper of the Economic Court of 24 October 2000.

${ }^{110}$ K Malfliet 'The Commonwealth of Independent States: Towards Supranationalism?', in F Feldbrugge (ed) Law in Transition (Kluwer Den Haag 2002). 
(complementarity or repetition) or conflict. ${ }^{111}$ The question arises about the ease with which it is possible to identify the rules comprising the applicable free trade regime and resolve potential conflicts. This does not matter only with regard to the implementation of the rules of the regime by the respective state organs, but also sends important signals to private actors. The issue deserves an extensive discussion, yet here we limit ourselves to drawing attention to some of its key aspects.

In the case of Russia, which has not ratified the 1994 or 1999 FTA, there is an overlap between the bilateral FTAs and the specific-issue multilateral agreements with its participation (Table 3) some of which were concluded earlier (eg on standards), others later (eg on reexport). The situation is more complicated as far as the other CIS countries are concerned. The 1994 FTA has entered into force with regard to all of them (except Turkmenistan) and is followed by the bilateral FTAs (Table 2). Similar to the case of Russia, they have joined a range of specific-issue multilateral agreements. As also noted, in some areas, there have been bilateral specific-issue agreements (eg customs cooperation).

The relationship between the norms of these agreements is largely determined by the use of conflict avoidance clauses:

- Many specific-issue multilateral agreements contain clauses, whereby their provisions 'do not affect (zatragivaiut)' the provisions of other international agreements in

${ }^{111}$ For a comprehensive analytical discussion of how norms interact with each other, see $\mathrm{J}$ Pauwelyn Conflict of Norms in Public International Law (Cambridge University Press Cambridge 2003), also A Aust Modern Treaty Law and Practice (Cambridge University Press Cambridge 2000). 
which the parties participate. ${ }^{112}$ Thus, arguably in the event of conflict the norms of earlier adopted treaties will prevail.

- The 1994 and 1999 FTA contain a conflict clause, whereby nothing in these treaties 'prevents any of the contracting parties from implementing the obligations under other agreements in which this contracting party participates or can participate, as long they do not contradict the provisions and objectives of this agreement'. ${ }^{113}$ Thus, these agreements allow for compatible supplementing agreements, adopted either earlier or later.

Not all specific-issue multilateral agreements, however, contain conflict avoidance clauses. ${ }^{114}$ Similarly, while approximately a third of the 'spoke' bilateral FTAs analyzed make a reference in their preambles to the multilateral FTA, they do not include a specific conflict norm. ${ }^{115}$ In such cases, the rules of the Vienna Convention, such as the lex posterior principle envisaged in Article 30, will be used to reach a conclusion on the applicable law.

In all instances - whether a conflict avoidance clause is envisaged or not - it is essential to determine the existence of 'conflict' or 'compatibility' between the norms of the different agreements by examining their substantive contents. Certainly, this examination is made easier when complementarity is established by virtue of reference

\footnotetext{
${ }^{112}$ Eg Art 5 of the 1998 Indirect Taxation Agreement, Art 11 of the 1999 Customs Clearance and Customs Control Agreement, Art. 15 of the 2000 Technical Barriers Agreement.

${ }^{113}$ Art 20.

${ }^{114}$ Eg the 1992 Standardization, Metrology and Certification Agreement, the 1995 Customs Nomenclature Agreement, or the 2000 Protocol on Licensing Imports.

115 The bilateral FTAs include conflict avoidance norms regarding earlier concluded compatible bilateral agreements or norms reflecting the pacta tertiis rule of Art 34 of the Vienna Convention. Clearly, these norms, as well as the Preamble references where made, will serve as grounds for interpretation.
} 
norms (eg on the use of the multilateral rules of origin) or when specific-issue multilateral agreements deal with previously unresolved subject-matter. Nonetheless, it becomes clear that the interpretation of norms - substantive ones but also the conflict avoidance clauses themselves - assumes a particular importance.

A help in this direction is the provision contained in many CIS agreements that disputes on interpretation should be resolved by reference to their definition in international agreements, such as the GATT/WTO agreements. Yet, this only underscores the need for effective domestic and regional institutions vested with interpretative powers. In principle, the Economic Court of the CIS is authorized to interpret the provisions of the agreements and other acts of the CIS on economic matters, and has used them, as shown above. ${ }^{116}$ Yet, the misgivings expressed with regard to the role of the Court in the CIS apply. Furthermore, the Court has not been granted powers of control over the legality of acts of the CIS organs or powers in the case of conflicts of existing rules $^{117}$ Despite toying with the idea, the Council of Heads of States has resisted turning the Economic Court into a constitutional or quasi-constitutional court of the kind of the European Court of Justice. ${ }^{118}$

\section{A VIEW OF THE PRESENT: ‘MULTIPLE BILATERALISM’ AND SELECTIVE MULTILATERALISM}

\footnotetext{
${ }^{116}$ Art 5 of the Statute of the Economic Court, Art 32 of the CIS Charter.

${ }^{117}$ In a few of its interpretations, however, the Court has ventured to recommend improvements in existing acts, such as the 1996 Procedural Rules of the Council of Heads of State Regarding the Decisions of the Council, Advisory Opinion of 15 May 1996.

118 The May 1995 Summit of the Council of the Heads of State decided on working on a Convention to establish a Court of Justice for the CIS, but it was left without consequence, see Danilenko (n 41).
} 
The preceding discussion leads us to view the present-state of the CIS trade institutions as a symbiosis between bilateral and multilateral regimes. Despite their evolution and the differences observed between them, both can be characterized as weak regimes.

Looking at the bilateral FTAs, it can be noted that their conclusion has evolved beyond the pre-1994 hub-and-spoke pattern. Yet later agreements continue to reproduce the early Russian templates with adjustments. In terms of their substantive provisions, the bilateral FTAs cover some key free trade rules, yet they remain minimal and quite basic. They include core issues such as tariffs, but remain generally lacking in relation to nontariff barriers. Certainly issues like technical requirements and standards, or any of the more recent trade issues, such as liberalisation of services, investment, intellectual property, environmental or labour issues are excluded. Many provisions are left vague and imprecise. Furthermore, often one is left to wonder whether the choice of certain provisions or their omission is deliberate, or simply the result of insufficient understanding of the subject-matter and/or bad copying of the early templates. Many agreements contain references to more detailed specific-issue multilateral instruments, yet the practice is not universal. Importantly, the bilateral FTAs rely on a soft institutional framework of disciplines. Disputes regarding their interpretation and application are resolved nearly always through consultation, even when related to unilaterally introduced special protective measures.

At the same time, it should be acknowledged that a certain evolution of the bilateral regimes has taken place and some (albeit limited) improvement of the quality of their provisions can be observed. This development is clearest in terms of the increasing 
number of references to related GATT/WTO regulation, most notably in the area of special trade measures. One needs to single out, in particular, 'new generation' agreements such as the 2003 Ukraine - Moldova FTA. While still immature compared to recent FTAs concluded by the EU, US, or EFTA, for example, the agreement represents a hopeful break with the pre-existing template both in substantive and institutional terms. It is clearly drafted with the membership of Moldova and Ukraine's advanced application to the WTO in mind and can be a possible example for further improvement of the bilateral FTAs.

The multilateral regime, in principle, aims to reach further than the bilateral FTAs both in terms of comprehensiveness, quality of rules, and provision for greater credibility of the commitments. While it leaves out some modern 'trade plus' issues, like environment or labour protection, and there certainly is a scope for improvement of its existing rules in comparison to those of other regional regimes, there has been some positive evolution from the 1994 to the 1999 package. This process (like improvements on the bilateral level) can be explained by reference to the accumulated learning experience as well as the progress made by countries in complying (at least by reforming law on the books) with WTO-requirements in the context of their applications for membership.

We specifically stressed the weakness of the system of disciplines of the multilateral regime. In fact, leaving the often questionable role of the Economic Court aside, the remaining provisions amount in substance to a regime more minimal than the early GATT. ${ }^{119}$ Developments on the multilateral level are also affected - for good and for bad

\footnotetext{
${ }^{119}$ Reich (n 8).
} 
- by the dynamics of CIS general institution building and its broader objectives as a regional organization. We noted the adverse effects of the combination between the application of the interested party principle and the fragmentation of the regime into framework and detailing agreements. At the same time, the changing goal-posts in determining the economic integration agenda in the CIS as well as the frequent incremental reforms of the organization's bodies lead to uncertainty and affect the overall credibility of the project.

The problems are exacerbated by issues of regional geopolitics in the post-Soviet space. As noted, Russia's lack of ratification of the general FTAs seems to compromise their fate regardless of the fact that they have entered in force with regard to all remaining CIS countries (except Turkmenistan). Indeed, this has been enough to make many take the view that there is no multilateral free trade framework in the CIS. We point out, however, that Russia has pursued the multilateral route in relation to selected issues, such as tariff classification, customs documentation, rules of origin, certification and standards. Thus, in the experience of the CIS, multilateralism with the participation of a hegemonic power works better in the realm of the more 'technical' aspects of trade rather than at the level of general institutions and in areas where clear domestic sensitivities are involved. In such 'technical' issues, arguably, there is an advantage in reducing the costs of bilateral negotiations and pooling legal resources, particularly beneficial for the smaller CIS countries.

Given the low or ineffective delegation at the CIS level in terms of decision-making and, particularly, dispute resolution, this 'a la carte multilateralism' and its overlap with what can be termed 'multiple bilateralism' amounts to a confusing and non-transparent 
regime. While some of this overlap may lead to beneficial complementarity (eg in relation to rules of origin or the negotiation of exemptions), it also leads to a lot of repetition and may require complex conflict avoidance analysis, as discussed above. The situation is aggravated by the general context of the still ineffective, often corrupt, and only gradually modernizing public administrative branches (including customs institutions) and judiciaries in former Soviet countries. ${ }^{120}$

\section{IN PLACE OF CONCLUSIONS: A VIEW OF THE FUTURE}

In this article we started from the premise that regional trade is good. Arguments in support of this thesis in the CIS context have been advanced by a number of international institutions, such as UNECE and the World Bank. The justification is made with regard to both domestic benefits and enhancing the region's contribution to international trade. Arguably, at least on a general level, there is also a consensus on that in the CIS countries themselves.

The issue remains, however, what institutional framework would contribute to the realization of the benefits from free trade while accounting for the political, legal and economic realities of the CIS region. As discussed above, clearly, the present state of affairs is deeply unsatisfactory in a number of ways.

Some commentators advise the renegotiation of FTAs, particularly moving from the system of bilateral free trade agreements to a new, effective multilateral agreement, accompanied by replacing the 'spaghetti bowl' of related transit and customs agreements

${ }^{120}$ Some general comparative information on the state of governance, rule of law and corruption can be obtained from <http://www.worldbank.org/wbi/governance/index.html>. 
by straightforward and clear plurilateral ones. ${ }^{121}$ Similarly, they propose the advancement in the substance of the agreements (eg elimination of contingent protection clauses) and the strengthening of the institutional capacity for enforcement. Certainly, the need for a more effective dispute-resolution mechanism has been widely noted. These recommendations coincide with the general trend of both bilateral and multilateral trade agreements, particularly pronounced as of the 1990s, for greater juridicization in substance as well as institutions. ${ }^{122}$

We agree in principle with most of these recommendations. We also agree with the applicability to the CIS context of many of the arguments which support the spread of juridicization. ${ }^{123}$ Yet, what the development of the CIS free trade regime to date shows is that there are important sensitivities and costs associated with the efforts to establish a comprehensive and binding multilateral regime. Without being exhaustive we note some of them, namely:

- the high sovereignty sensitivities of countries that have been independent only since 1991, leading to reluctance for 'hard' arrangements.

- the high negotiation and implementation costs associated with the unfinished and varied pace of reform of the political systems, in general, and public administration, in particular, of the different CIS member states.

- the extreme inequalities of bargaining power related to Russia's critical role which allows it to rule both bilateral and multilateral routes and often reinforces the cycle of

\footnotetext{
${ }^{121}$ Freinkman et al (n 4) 53.

${ }^{122}$ Reich (n 8).

${ }^{123}$ Dr. Reich refers to factors ranging from natural evolution, to influence of ideological changes, to increase of economic interdependence.
} 
distrust and unwillingness of the rest of the CIS member states to subject themselves to binding institutions.

- the compromised state of the multilateral economic integration project after fifteen years of partial and ineffective reform.

In addition to these realities favoring 'soft' forms of cooperation, the development of trade regimes post-World War II shows that in many settings juridicization is only gradually achieved. Some arguments have been made that it is within the sub-regional groupings (like the EAC or SES) that the future lies. We leave the discussion of this point for another article, yet we remain skeptical of the extent to which the legal institutions of these formations are qualitatively different from the CIS arrangements.

Thus, while we recognize the important learning that has already occurred, we remain weary of the possibility to 'harden' the institutional framework in the CIS and consolidate it at the multilateral level at least in the short- and medium-term.

Table 1: Applications and accessions to the WTO

\begin{tabular}{|l|l|l|l|}
\hline & \multicolumn{1}{|c|}{ Application } & First Work Party meeting & Accession \\
\hline Russian Federation & June 1993 & July 1995 & \\
\hline Belarus & September 1993 & June 1997 & \\
\hline Ukraine & November 1993 & February 1995 & \\
\hline Moldova & November 1993 & June 1997 & 26 July 2001 \\
\hline Armenia & December 1993 & January 1996 & 5 February 2003 \\
\hline Uzbekistan & December 1994 & July 2002 & \\
\hline Kazakhstan & January 1996 & March 1997 & \\
\hline Kyrgyz Republic & February 1996 & March 1997 & 20 December 1998 \\
\hline Georgia & June 1996 & March 1998 & 14 June 2000 \\
\hline Azerbaijan & June 1997 & June 2002 & \\
\hline Tajikistan & May 2001 & March 2004 & \\
\hline Turkmenistan & - & - & \\
\hline Sourc:WTO & & &
\end{tabular}

Source: WTO. 
Table 2: Bilateral FTAs analysed

\begin{tabular}{|l|c|}
\hline \multicolumn{1}{|c|}{ Countries } & Date FTA \\
\hline Russian Federation - Armenia & 30.09 .1992 \\
\hline Russian Federation - Azerbaijan & 30.09 .1992 \\
\hline Russian Federation - Kyrgyz Republic & 8.10 .1992 \\
\hline Russian Federation - Tajikistan & 10.10 .1992 \\
\hline Russian Federation - Kazakhstan & 22.10 .1992 \\
\hline Russian Federation - Turkmenistan & 11.11 .1992 \\
\hline Russian Federation - Belarus & 13.11 .1992 \\
\hline Russian Federation - Uzbekistan & 13.11 .1992 \\
\hline Ukraine - Belarus & 17.12 .1992 \\
\hline Russian Federation - Moldova & 9.02 .1993 \\
\hline Russian Federation - Ukraine & 24.06 .1993 \\
\hline Russian Federation - Georgia & 3.02 .1994 \\
\hline & \\
\hline Ukraine - Kazakhstan & 17.09 .1994 \\
\hline Ukraine - Armenia & 7.10 .1994 \\
\hline Ukraine - Uzbekistan & 29.12 .1994 \\
\hline Ukraine - Georgia & 9.01 .1995 \\
\hline Ukraine - Kyrgyz Republic & 26.05 .1995 \\
\hline Moldova - Kyrgyz Republic & 26.05 .1995 \\
\hline Moldova - Kazakhstan & 26.05 .1995 \\
\hline Kazakhstan - Kyrgyz Republic & 22.06 .1995 \\
\hline Kazakhstan - Tajikistan & 22.11 .1995 \\
\hline Georgia - Azerbaijan & 8.03 .1996 \\
\hline Georgia - Turkmenistan & 20.03 .1996 \\
\hline Ukraine - Kyrgyz Republic & 26.05 .1996 \\
\hline Uzbekistan - Azerbaijan & 27.05 .1996 \\
\hline Kyrgyz Republic - Uzbekistan & 24.12 .1996 \\
\hline Kazakhstan - Uzbekistan & 2.06 .1997 \\
\hline Kazakhstan - Azerbaijan & 10.06 .1997 \\
\hline Kazakhstan - Belarus & 23.09 .1997 \\
\hline Kazakhstan - Georgia & 11.11 .1997 \\
\hline Belarus - Tajikistan & 3.09 .1998 \\
\hline Belarus - Kyrgyz Republic & 30.03 .1999 \\
\hline & 2.09 .1999 \\
\hline Kazakhstan - Armenia & 18.01 .2000 \\
\hline Belarus - Armenia & 19.01 .2000 \\
\hline Kyrgyz Republic - Tajikistan & 6.07 .2001 \\
\hline Ukraine - Tajikistan & 31.03 .2004 \\
\hline Ukraine - Moldova & \\
\hline Belarus - Azerbaijan & $29.08 .1995,13.11 .2003$ \\
\hline Sourc: Ow FTA signed & \\
\hline
\end{tabular}

Source: Own compilation. 
Table 3: Key multilateral agreements in force related to CIS free trade

\begin{tabular}{|c|c|c|c|c|c|c|c|c|c|c|c|c|}
\hline Multi-lateral agreements & $A M$ & $A Z$ & BY & GE & $K G$ & $K Z$ & MD & $\boldsymbol{R U}$ & $T M$ & $T J$ & UA & $U Z$ \\
\hline \multicolumn{13}{|l|}{ General (framework) agreements } \\
\hline On the Principles of Customs Policy, 13.03.1992 & $\mathrm{S}$ & - & $\mathrm{R}$ & - & - & $\mathrm{s}$ & $\mathrm{s}$ & $\mathrm{s}$ & $\mathrm{S}$ & $\mathrm{R}$ & - & $\mathrm{R}$ \\
\hline Treaty on the Economic Union, 24.09.1993 & $\mathrm{R}$ & $\mathrm{R}$ & $\mathrm{R}$ & $\mathrm{R}$ & $\mathrm{R}$ & $\mathrm{R}$ & $\mathrm{R}$ & $\mathrm{R}$ & $\mathrm{R}$ & $\mathrm{R}$ & - & $\mathrm{R}$ \\
\hline On the Free Trade Area, 15.04.1994 & $\mathrm{R}$ & $\mathrm{R}$ & $\mathrm{R}$ & $\mathrm{R}$ & $\mathrm{R}$ & $\mathrm{R}$ & $\mathrm{R}$ & $\mathrm{S}$ & $\mathrm{s}$ & $\mathrm{R}$ & $\mathrm{R}$ & $\mathrm{R}$ \\
\hline $\begin{array}{l}\text { Protocol Amending the Agreement on the Free Trade Area, } \\
\text { 2.04.1999 }\end{array}$ & $\mathrm{R}$ & $\mathrm{R}$ & $\mathrm{R}$ & $\mathrm{R}$ & $\mathrm{R}$ & $\mathrm{R}$ & $\mathrm{R}$ & $\mathrm{S}$ & - & $\mathrm{R}$ & $\mathrm{R}$ & $\mathrm{R}$ \\
\hline \multicolumn{13}{|l|}{ Specific issue agreements } \\
\hline On Standardization, Metrology and Certification, 13.03.1992 & $\mathrm{R}$ & $\mathrm{R}$ & $\mathrm{R}$ & $\mathrm{R}$ & $\mathrm{R}$ & $\mathrm{R}$ & $\mathrm{R}$ & $\mathrm{R}$ & $\mathrm{R}$ & $\mathrm{R}$ & $\mathrm{R}$ & $\mathrm{R}$ \\
\hline On Rules of Origin, 24.09.1993(Decision) & $\mathrm{R}$ & $\mathrm{R}$ & $\mathrm{R}$ & - & $\mathrm{R}$ & $\mathrm{R}$ & $\mathrm{R}$ & $\mathrm{R}$ & $\mathrm{R}$ & $\mathrm{R}$ & $\mathrm{R}$ & $\mathrm{R}$ \\
\hline On the Re-export of Goods, 15.04.1994 & $\mathrm{R}$ & $\mathrm{R}$ & $\mathrm{R}$ & $\mathrm{S}$ & $\mathrm{R}$ & $\mathrm{R}$ & $\mathrm{S}$ & $\mathrm{R}$ & $\mathrm{s}$ & $\mathrm{R}$ & $\mathrm{s}$ & $\mathrm{R}$ \\
\hline On Co-operation in Customs Affairs, 15.04.1994 & $\mathrm{R}$ & $\mathrm{R}$ & $\mathrm{R}$ & $\mathrm{s}$ & $\mathrm{R}$ & $\mathrm{R}$ & $\mathrm{R}$ & $\mathrm{R}$ & $\mathrm{s}$ & $\mathrm{R}$ & $\mathrm{R}$ & $\mathrm{R}$ \\
\hline $\begin{array}{l}\text { On the Foundations of Customs Legislation, 10.02.1995 } \\
\text { (Decision) }\end{array}$ & $\mathrm{s}$ & $\mathrm{R}$ & $\mathrm{R}$ & $\mathrm{S}$ & $\mathrm{R}$ & $\mathrm{R}$ & $\mathrm{S}$ & $\mathrm{R}$ & - & $\mathrm{R}$ & $\mathrm{s}$ & $\mathrm{R}$ \\
\hline On the Single Commodities Nomenclature, 3.11.1995 & $\mathrm{R}$ & $\mathrm{R}$ & $\mathrm{R}$ & $\mathrm{R}$ & $\mathrm{R}$ & $\mathrm{R}$ & $\mathrm{R}$ & $\mathrm{R}$ & $\mathrm{R}$ & $\mathrm{R}$ & $\mathrm{R}^{*}$ & $\mathrm{R}$ \\
\hline On The Principles of Indirect Taxation, 25.11.1998 & $\mathrm{R}$ & $\mathrm{R}$ & $\mathrm{R}$ & $\mathrm{S}$ & $\mathrm{R}$ & - & $\mathrm{R}$ & - & $\mathrm{R}$ & $\mathrm{R}$ & - & - \\
\hline On Rules of Transit, 4.06.1999 & $\mathrm{R}$ & $\mathrm{R}$ & $\mathrm{R}$ & $\mathrm{S}$ & $\mathrm{S}$ & $\mathrm{R}$ & $\mathrm{R}$ & $\mathrm{R}$ & - & $\mathrm{R}$ & $\mathrm{R}$ & $\mathrm{S}$ \\
\hline $\begin{array}{l}\text { On the Procedure for Customs Clearance and Customs Control, } \\
\text { 8.10.1999 }\end{array}$ & $\mathrm{R}$ & $\mathrm{R}$ & $\mathrm{s}$ & $\mathrm{s}$ & $\mathrm{R}$ & $\mathrm{R}$ & $\mathrm{R}$ & $\mathrm{R}$ & - & $\mathrm{R}$ & $\mathrm{R}$ & $\mathrm{s}$ \\
\hline On the Technical Barriers in the Free Trade Area, 20.06.2000 & $\mathrm{R}$ & $\mathrm{R}$ & $\mathrm{R}$ & $\mathrm{S}$ & $\mathrm{R}$ & $\mathrm{R}$ & $\mathrm{R}$ & $\mathrm{S}$ & - & $\mathrm{R}$ & $\mathrm{s}$ & $\mathrm{S}$ \\
\hline On Rules on Origin, 30.11.2000 (Decision) & $\mathrm{R}$ & $\mathrm{R}$ & $\mathrm{R}$ & $\mathrm{R}$ & $\mathrm{R}$ & $\mathrm{R}$ & $\mathrm{R}$ & $\mathrm{R}$ & - & $\mathrm{R}$ & $\mathrm{R}$ & - \\
\hline On the Rules for Licensing Imports, 30.11.2000 (Protocol) & $\mathrm{R}$ & $\mathrm{R}$ & $\mathrm{R}$ & $\mathrm{S}$ & $\mathrm{S}$ & $\mathrm{s}$ & - & $\mathrm{s}$ & - & $\mathrm{R}$ & $\mathrm{R}$ & - \\
\hline
\end{tabular}

Source: Own compilation.

s - signed (acceded); R - ratified (or other transformation procedure); - neither; $\mathrm{R}^{*}$ - denounced participation.

The abbreviations used read as follows: AM - Armenia, AZ - Azerbaijan, BY - Belarus, GE - Georgia, KG - Kyrgyzstan, KZ - Kazakhstan, MD

- Moldova, RU - Russian Federation, TM - Turkmenistan, TJ - Tajikistan, UA - Ukraine, UZ - Uzbekistan. 